RAGO, Margareth. A aventura de contar-se. Campinas: UNICAMP, 2013.

\title{
A perspectiva feminista da escrita de si
}

\section{The feminist perspective of writing itself}

Daniele Beatriz Manfrini1

'A aventura de contar-se' é um livro sobre a história de vida e a 'escrita de si' de sete mulheres contemporâneas ao período da ditadura militar, que sofreram as agruras deste, ao mesmo tempo que trilharam caminhos ao encontro do feminismo em suas diferentes vertentes e expressões, o que norteou as mudanças significativas em suas vidas pessoais e profissionais. A autora busca destacar as experiências miúdas e intensas de mulheres, obscurecidas pelas história oficial e que levam a um novo modo de pensar e agir.

Escrito por uma historiadora com expressivo conhecimento nos estudos de gênero, a obra aborda de maneira bem articulada a pesquisa de campo e os referenciais teóricos da área da história e dos estudos feministas. Foucault é o principal autor que norteia as discussões teóricas e junto com Derrida e Deleuze, tem conceitos importantes articulados aos temas analisados na pesquisa.

A 'escrita de si' é o centro da metodologia da pesquisa, que no entender da autora, abre possibilidade de uma relação renovada de si para consigo e para com os outros. Difere da biografia e de outras técnicas, justamente por possibilitar às pesquisadas a avaliação de suas próprias escolhas e análise das consequências em suas vidas, reconhecendo a escrita de si como uma forma de autonomia e afirmação das subjetividades. Ao mesmo tempo que para a autora a escrita de si denota a posição das mulheres priorizando o cuidado com

\footnotetext{
${ }^{1}$ Doutoranda do Programa de Pós-Graduação Interdisciplinar em Ciências Humanas, Universidade Federal de Santa Catarina. danielebeatriz@ hotmail.com
} 
o outro e fragmentações da identidade delas, tanto pelas interrupções quanto descontinuidades em diferentes situações e fases da vida. Enfatiza que a subjetividade feminina é marcada por violências, repressões e controles muito particulares.

A autora entrevistou sete mulheres, contemporâneas entre si, cuja história de vida está ligada aos feminismos em diferentes locais e espaços político-públicos, como o período da ditadura militar e os partidos políticos, a dinâmica da prostituição e o ambiente religioso. Com isso, de certa forma, analisa o momento do feminismo na cultura brasileira naquele período, diante da situação política e embates das mulheres no espaço público.

Além disso, colheu dados a partir de materiais autobiográficos, obras e trabalhos acadêmicos destas mulheres. Apresenta as especificidades pessoais e profissionais de cada uma. Por diferentes caminhos elas se aproximaram e mergulharam no feminismo, destacando-se como experiência comum a luta contra a normatividade imposta a elas e contra as novas formas de controle biopolítico sobre os corpos, contra os quais, comprometem-se a combater política e socialmente.

Na parte das 'Balizas', a título introdutório, a autora localiza as mulheres que entrevistou como sujeitos de sua pesquisa, o momento histórico em que viveram e os movimentos sociais no Brasil na época. Apresenta a metodologia escolhida para a pesquisa, fundamentando a 'escrita de si' a partir de Foucault e outros teóricos. Sugere utilizar a categoria de Walter Benjamin de contar a 'história a contrapelo', para evidenciar as ausências de registros na história oficial, principalmente das passagens discursivas do privado, tipicamente das mulheres, que devem ser apropriadas pelo público. E ainda, a categoria de 'vidas nuas' de Agambem (2002) sobre a discussão de destruição de identidade.

Em 'Experimentações' apresenta as mulheres pesquisadas através das narrativas sobre suas histórias de vida e a participação no momento político-social, demonstrando que contar o passado é também uma forma de resistência, evidenciando fatos que diferem da história contada oficialmente pelos órgãos públicos e por narrativas masculinas. Ou seja, quebra o silêncio e a invisibilidade da narrativa das mulheres sobre o período da ditadura militar. 
Não menos importante que sobre a vida acadêmica e profissional, a apresentação das entrevistadas a partir de aspectos do cotidiano e da personalidade evidenciam as subjetividades, questões que para a perspectiva feminista, são parte da contextualização da história de vida das mulheres, importantes para a compreensão de suas escolhas.

Amelinha e Criméia, militantes do PCdoB, a segunda enfermeira que lutou na Guerrilha do Araguaia e a primeira, operária metalúrgica. Ambas relatam as torturas sofridas na prisão, inclusive violências sexuais. Diante dos diversos momentos de ruptura em suas vidas, recordam o passado como uma tentativa de superação da dor e reforço do desejo de justiça.

Ivone, paulistana que sai de casa para ser freira, aproxima-se da Teologia da Libertação trabalhando com Dom Helder Câmara e a partir da sua imersão no feminismo, vê-se frente a diversos embates e repreensões ao incluir as mulheres nos debates teológicos.

Norma Telles, paulistana, identifica-se como participante da linha da contracultura, que mesmo diferente de partidos políticos ou outros movimentos sociais, é também um movimento de resistência. No seus percursos de viagens, ela reflete sobre o conhecimento de si e aproxima-se das questões que envolvem o corpo e o contato com as emoções, imaginação e sonho, consideradas pela esquerda da época, como alienantes.

A história de Maria, paulistana envolta no urbano e moderno, destaca a importância de alguns membros familiares, como o irmão filósofo, com quem escreve uma revista de teor feminista em Paris; o companheiro Norberto e sua morte trágica nos porões da ditadura militar; e o nascimento da filha Marta que a acompanha tanto no período da faculdade, quanto no exílio em Cuba.

Tânia, nascida em Curitiba, foi estudar em São Paulo, Rio de Janeiro e posteriormente em Paris, onde conheceu a feminista Marie France Dépêche, que a introduziu nas leituras e movimentos feministas. As viagens foram parte da vida que a constituiu como historiadora feminista, a partir das mudanças subjetivas que levaram a novas reflexões e pesquisas. 
Gabriela, nasceu em família de classe média paulistana, foi estudar ciências sociais na USP e passou a viver com intensidade a vida política e boêmia, sobretudo da classe artística. Como ela mesma narra, optou pela prostituição diante do convite de uma amiga, destacando, sobretudo, que não se reconhecia nos movimentos estudantis, tampouco com a luta armada, apesar de ter feito a sua 'revolução sexual' em razão do meio acadêmico que vivia. Sofreu os preconceitos enfrentados pelas prostitutas e foi presença fundamental no movimento nacional das prostitutas.

$\mathrm{Na}$ parte que intitula 'Cartografias', a autora apresenta a relação destas mulheres com os movimentos sociais e políticos nos quais se inserem e as organizações e entidades que criaram ou das quais participam, sejam ONGs, jornais ou revistas, além das carreiras acadêmicas e intercâmbios de estudos. Por outro lado, revela que quanto mais imergiam no ideário feminista, mais embates geravam em seus próprios grupos e movimentos sociais, nem sempre abertos a incluir a questão das mulheres, levando algumas delas e romperem com estes grupos.

Por fim, os capítulos 'Um lugar no mapa' e '...é também um lugar na história', trazem as reflexões das mulheres pesquisadas sobre os feminismos e o lugar em que se encontram nos movimentos e nas articulações feministas, como uma avaliação do percurso profissional e pessoal de militância. E assim, a autora também indica os encontros e desencontros entre o pensamento destas mulheres, que contemporaneamente e com os mesmos ideários feministas fizeram suas histórias e alcançaram os seus objetivos ou avaliaram o que poderiam ter feito de outra maneira.

Uma das grandes contribuições da obra é, a partir da escrita de si destas mulheres, despertar ou reforçar o exemplo das lutas feministas, inclusive mergulhando nas teorizações feministas introduzidas por suas experiências pessoais e percursos acadêmicos. Ou seja, é uma obra que além de apresentar a história de vida destas mulheres, inspira a reflexão nos próprios 'pensamentos de si' de cada leitor.

É um livro para quem deseja se 'aventurar' em uma forma de escrita tipicamente feminista que articula durante toda a obra as subjetividades e experiências das mulheres pesquisadas (e da própria 
autora), articulando-as às teorias que fundamentam a análise realizada. Um notável exemplo de como pesquisar e publicizar os dados, despertando nos leitores o desejo de conhecer mais a história brasileira não contada oficialmente e continuar revelando as histórias 'miúdas' de mulheres que, sendo ícones ou não, têm uma outra história para contar. 